\title{
The story of building healthful houses in East Nusa Tenggara, Indonesia
}

\section{A história da construção de casas saudáveis em Sonda Oriental, Indonésia}

\author{
Semiarto Aji Purwanto \\ aniversidade da Indonésia. Departamento de Antropologia. \\ Depok, Indonésia. \\ E-mail: semiarto.ajiog®ui.ac.id \\ Indraini Hapsari ${ }^{\text {b }}$ \\ bUniversidade da Indonésia. Departamento de Antropologia. \\ Depok, Indonésia. \\ E-mail: indraini.hapsari®ui.ac.id
}

\begin{abstract}
While the State plays an important role in actively transforming communities into conditions considered as 'developed', at the micro level there are some traditional features which persist. This short ethnographic observation carried out among the Dawan in the village of Oinlasi, South Amanatun, East Nusa Tenggara, revealed that the ume kbubu, a Timorese traditional house style, has experienced some changes as a consequence of the introduction of the Ministry of Health's 'healthful housing' program around fifty years ago. It was found that this program, along with other development programs, has changed the traditional life of the communities in the village. However, the researchers also witnessed that the communities were responding to these changes in various ways. The traditional houses were, in some cases, built with modern materials, equipped with electricity, and used only as a kitchen, while the family lived in modern healthful housing nearby. It is concluded that, although the idea of healthful houses is accepted by the community, their traditional house persists.
\end{abstract}

Keywords: Ume kbubu; Healthful House; Traditional House; East Nusa Tenggara; Indonesia; Development.

\section{Correspondence}

Semiarto Aji Purwanto

Departamento de Antropologia, Universidade da Indonésia.

Depok, Indonésia.

E-mail: semiarto.ajiogळui.ac.id 


\section{Resumo}

Enquanto o Estado desempenha um papel importante na transformação ativa das comunidades em condições consideradas "desenvolvidas", em nível micro algumas características tradicionais persistem. Esta breve observação etnográfica levada a cabo entre os Dawan na aldeia de Oinlasi, no sul de Amanatun, em Sonda Oriental, revelou que o ume kbubu, um estilo de casa tradicional timorense, sofreu algumas mudanças como consequência da introdução do programa de "habitação saudável" do Ministério da Saúde, há cerca de cinquenta anos. Verificou-se que esse programa, com outros programas de desenvolvimento, mudou a vida tradicional das comunidades na aldeia. No entanto, os pesquisadores também testemunharam que as comunidades estavam respondendo a essas mudanças de várias maneiras. As casas tradicionais eram, em alguns casos, construídas com materiais modernos, equipadas com eletricidade e usadas apenas como cozinha, enquanto a família vivia em casas modernas e saudáveis nas proximidades. Conclui-se que, embora a ideia de casas saudáveis seja aceita pela comunidade, suas moradias tradicionais persistem.

Palavras-chave: Ume kbubu; Casa Saudável; Casa Tradicional; Sonda Oriental; Indonésia; Desenvolvimento.

\section{Introduction}

Housing is of interest to the anthropologist, since it represents not only shelter for human beings but also an expression of cultural knowledge. Waterson (1990, p. 160) explains that "the study of inhabited space, its construction, and daily use, can provide a "way in' to a whole culture and its ideas". This view suggests that culture has an important role in understanding why certain houses are built, their shape, the choice of kinds of material of which they are made, and the purposes for which they are constructed. In Indonesia, today, houses and buildings are widely built using concrete materials such as bricks, tiles, and metals. Wood and a wide range of other organic materials are used in more limited amounts.

In addition to changes in the materials used to build houses, their functions and meanings have also changed. In some cases, traditional houses, with their unique functions and meanings, have been replaced by modern housing. Windi and Whittaker (2012) describe how ume kbubu, as an example of traditional housing, competes with the trend toward rumah sehat (healthful houses) introduced by the Indonesian government. It is said that, although people still build ume kbubu, they now live in modern rumah sehat, with the ume kbubu specifically transformed into a kitchen and food storage area. These authors explain this as being a consequence of modern health standards introduced by development.

As in other former European colonies, studies of the dynamics of housing and residence in Indonesia cannot be separated from the colonialist policies used in the past to control power. Harris (2009) suggests that British and Dutch policies on housing may have been related to political interests in controlling native populations. During the Dutch colonial era in Indonesia, people living scattered in forests or gardens were grouped into new compounds to create new towns. The Dutch set these towns up by building municipal offices, marketplaces, and housing, but at the same time allowed the city dwellers to maintain their kampung (villages) outside the towns. These arrangements, as Cobban (1993) indicates, resulted in residential compounds with poor facilities. 
In the case of the transformation of traditional houses, the colonial policies that were continued by the Indonesian government after independence have been somewhat similar, in that they aim to enhance the quality of life of the population through the building of more healthful houses. The idea of healthful living standards is derived from the code developed by the American Public Health Association's Committee on the Hygiene of Housing (1938), the US expert in public health. Winslow identified four principles for building ideal housing, these being that it should fulfill fundamental physiological needs, fundamental psychological needs, and provide protection against contagion and accidents. He argued that dwellings with poor facilities in slum areas in Manchester, England, indicated loss of "all humanity" and that inhabitants were "degraded, reduced morally and physically to bestiality" and could not "feel comfortable and at home". Discourse on healthful housing began in nineteenth century Europe (Krieger; Higgins, 2002, p. 76o), and since then the idea of healthful housing has become a necessity for all governments to fulfill. In Indonesia, the idea of healthful housing was continued by the government through the building of massive numbers of healthful houses in the 1950 os.

Unfortunately, many kinds of traditional houses, such as the honai in Papua and the Dayak longhouse in Kalimantan, fit the definition of unhealthy housing. Limited air circulation caused by indoor burning of biomass and lack of ventilation has been accused of being the cause of "the second biggest environmental pollutant contributor to ill health in the world" in research conducted in Wamena, Papua (Rantetampang et al., 2013). In Kalimantan, the incidence of malaria grew rapidly in longhouses (Leaman et al., 1995).

The government issued a ministerial decree to regulate and guide communities in the building of healthful houses, namely the Decree of the Minister of Health No. 829, 1999, on the conditions for healthful houses. This decree, aside from previous programs on healthful houses, was ultimately intended to eliminate traditional houses in Indonesia. According to the Head of the Sub-district at Oinlasi, healthful houses are justified by the outbreak of tuberculosis in the 1980 s. He also said that malaria is endemic in Oinlasi and that mosquito bites must be avoided. Ume kbubu, which lack ventilation, are believed to be favorable places for mosquitoes to live, making living in such homes potentially risky. The government is therefore maintaining the program for promoting healthful houses and their benefits for health (Prasodjo et al., 2015).

Since ume kbubu and other traditional houses were designated as not healthful, and as change to such housing was pushed by the government, the phenomenon of the continued existence of such houses needs to be investigated. While Windi and Whittaker (2012) offered an explanation for the continuity of ume kbubu, the aim of this study is to explain this further, from the perspective of development discourse. The researchers would like to argue that the continuity and persistence of the use of ume kbubu among the Dawan in Oinlasi demonstrates the performance of development, and at the same time illustrates the dynamic of local institutions to survive.

\section{Methods}

The data was collected from a short ethnographic observation in Oinlasi Village, in the southern part of So'e, the capital city of the Timor Tengah Selatan Regency. The rules for conducting ethnographic studies set up by Hammersley and Atkinson (1993, p. 3) were followed, directing fieldworkers to study people's actions and accounts in everyday contexts and to collect data from various sources, including secondary data. Moreover, these authors also highlight that the nature of ethnographic research is to allow researchers to be open to many findings in the field. Thus, the research design for this study was fairly unstructured, and focused on case studies of small-scale situations.

The researchers lived in the community for two months in 2016 and for a further month in 2017, gathering data for the Program Desa Mitra (Village Partnership Program) managed by the Center for Research and Integrated Development of Tropical Health and Infectious Diseases, University of Indonesia. A few social and cultural aspects of health behavior in the community were investigated. There was, however, another topic of interest related to the 
existence of traditional houses in Dawan: despite the campaign to build healthful houses, there were still a number of these traditional houses in the villages. Therefore, some in-depth interviews were conducted with key respondents, including community leaders, health practitioners, teachers, farmers, and religious and cultural figures.

For a more gender sensitive reason, both men and women were used as informants. In some cases, conversation about houses in Dawan is considered to be women's domain, since it is regarded as a domestic issue, while men play most of the important public roles as leading persons in the village. Nine men and eleven women from Oinlasi were chosen as respondents, comprising village leaders, teachers, paramedics in the local health center, a priest, local entrepreneurs, farmers, and housewives. In addition, to expand the knowledge acquired and to compare findings, data was also collected from ten people living in villages adjacent to Oinlasi.

\section{Results and discussion}

\section{The sociocultural backgrounds of the community}

Oinlasi is one of thirteen villages belonging to South Amanatun Subdistrict, South Central Timor Regency. Being the capital city, it is the village with the highest population density in the subdistrict. In 2016, the population of Oinlasi reached 2,265 people, while the average population in the subdistrict is of only 1,418 people in each village. With an area of $3.09 \mathrm{~km}$, the population density of Oinlasi is 733 people $/ \mathrm{km}^{2}$ (Central Bureau of Statistics of South Central Timor District 2017, p. 14).

The majority of the population of South Central Timor Regency is a Dawan (Situmeang 2013), one of the indigenous groups of Timor Island. Based on the Ministry of Social Affair's record, $61 \%$ of people in West Timor is the Dawan (Windi; Whittaker, 2012, p. 1154). Though commonly known as the Timorese by the Dutch, the locals call themselves Atoni Pah Meto or simply the Meto people, which is widely used to refer to mountain people in Timor (McWilliam, 2006; Situmeang, 2013, p. 19). Meanwhile, our informants in Oinlasi prefer to call themselves as Dawan people to refer to the language they use daily.
By 2015, the majority of the population of South Central Timor Regency is Protestant with $82.73 \%$, followed by the Catholic with $14.9 \%$, and the rest belongs to Islam and Hinduism (Central Bureau of Statistics East Nusa Tenggara Province 2016, p. 210). Although the region is one of the first Protestant regions in the province of East Nusa Tenggara (Wadu et al., 2003, p.15-16), traditions based on local faith are still widely practiced. To call their almighty God, they refer to Uis Neno or the sun god. Uis Neno is also known as Amoet Afakaet, which means "the creator and king". In addition to the supernatural figures, the Timorese greatly respect the corn (pena), which they regard as king (usim nahat). Various rituals are performed during the process of planting corn, before harvest time, until the moment it is ready to eat. If corn occupies the position of king, then ume kbubu becomes its palace. Moreover, ume kbubu also serves as the residence of the guards of the king (aauba), which is represented by green beans, red beans, rice beans, and nuts. Ume kbubu's door, which is only about one meter in height, has two functions: to keep the house warm, and to force adults who enter to bend over. Entering with a bow is part of the tribute to their gods.

Throughout his life, the individual is surrounded by other human beings, uis neno, and a group of ancestral spirits. As it occupies a central position in life, the individual must pray and ask for uis neno's protection. However, no one can directly deal with his uis neno. The individual would then need to communicate intensely with his ancestral spirits, as an intermediary to God. The spirits of the deceased are considered to have joined the uis neno in order to connect themselves to those who live with uis neno (Maria; Limbeng; Sunarto, 2006, p. 76-78). The linkage between humans, uis neno, and ancestral spirits in the life of the Timorese explains why the pre-Protestant beliefs and rituals are still persistent despite the presence of Protestantism.

\section{The traditional ume kbubu}

The traditional house of ume kbubu has a round shape in the upper part of the house. The materials used to build the house can be found from the natural surroundings (Dima; Antariksa; Nugroho, 2013). The 
roof of an ume kbubu is shaped like a hairstyle that is rounded and tapered at the top. Dawan people regard it as the symbol of a woman, especially a mother. Ume kbubu is also referred to as ume bife, which literally means 'house of the woman', where various activities ranging from cooking and weaving to childbirth are carried out.

\section{Figure I - Typical form of an ume kbubu house}

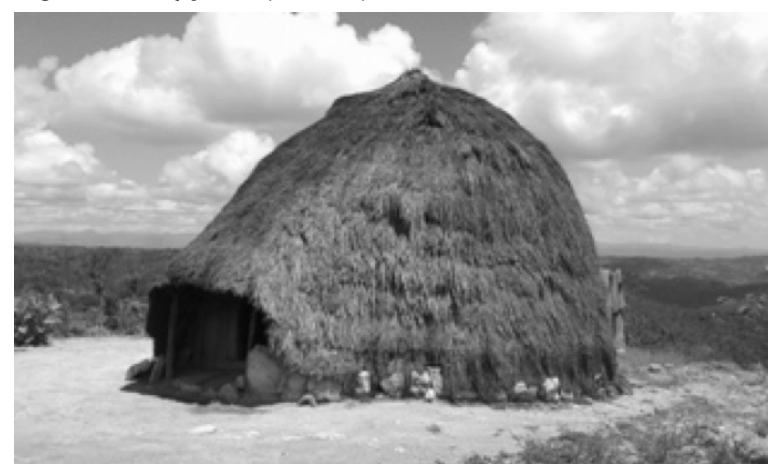

In the past, ume kbubu was the main house for farmers. The main commodity of Timorese farmers is the corn, which is their staple food, and ume kbubu serves as a barn to store corn and to preserve it with smoke. Smoking, or se' $i$, is carried out to preserve corn, green beans, and red beans. Se'i decreases the moisture content of the corn, while the soot that results from this fumigation coats the surface of the corn grains so that bug-like insects cannot easily penetrate them. A recent study revealed that the function of ume kbubu for food storage explains why such houses are still maintained in the community today (Situmeang, 2013). This process of 'smoking' was also traditionally used as part of confinement practices, in that a newborn baby and its mother were 'heated up' by se' $i$ for the first 40 days after birth.

Another special aspect of ume kbubu is the doors to the houses, which are only about one meter in height, meaning that adults entering must bend over or 'bow'. These short doors prevent the smoke for corn preservation from escaping from the houses. Besides having this practical function, the short ume $k b u b u$ door aims to encourage the person entering into the building to bow, which has a symbolical meaning of respect for the foodstuffs stored inside, especially corn.
Figure 2-Smoked corns hanged inside the ume kbubu

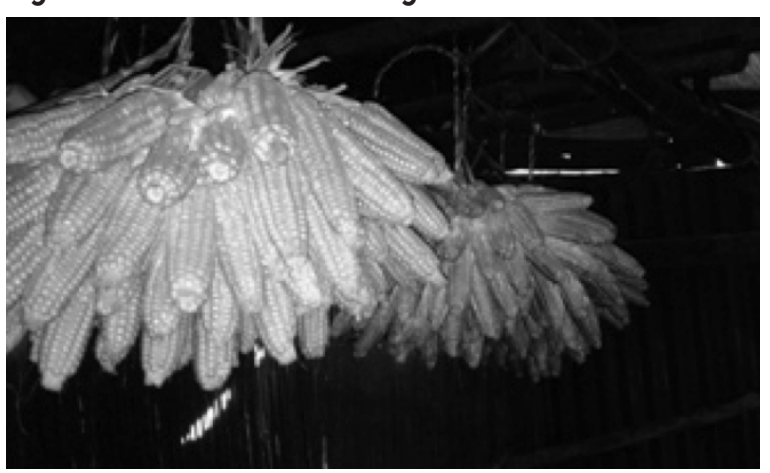

By understanding the functions of ume kbubu for the people of Timor, the importance of the role of ume kbubu for them, both practical and symbolic, can be understood. The significance of ume kbubu leads some Timorese to maintain these traditional buildings, even though, today, many people build healthful homes as well, which is what happens in most cases for the residents of Oinlasi Village.

\section{Building healthful houses as a form of modernization}

According to the Head of the Sub-District of South Amanatun, modernization has changed Timorese communities, especially in terms of their dwellings. As stated earlier, in the past, the Timorese only had ume kbubu in which to perform all their activities, including sleeping, receiving guests, gathering with their family, cooking, weaving, storing corn, and a place for mothers to give birth. However, since the modernization program (dating back to the 1980s), the Timorese now mostly use ume kbubu only as a place to cook and store corn. The location for sleep and family gatherings is a large, modern house that is considered to be healthful.

Modernization is a central concept in the discourse of economic growth. From the perspective of modernization, a community will be seen to continue to develop during the process of industrialization and urbanization, and the differences between communities will gradually disappear, while at the same time the scale and complexity of the social division of labor will increase (Gabriel, 1991, p. 10). The pressure of modernization also raises issues related to functional adaptation, in which some societies can 
adapt better than others. Thus, society will be seen as divided into two poles, "traditional" and "modern".

Returning to the ume kbubu case in Oinlasi, and trying to analyze it using the modernization concept, it can be said that the people who live in ume kbubu are considered as traditional people. Labeling like this can be easily done because one part of the community is seen to be at a more advanced level than the rest of society. Or, if we return to the above-mentioned definition of modernization, people who have moved into modern houses are more successfully performing functional adaptations than those still living in ume kbubu. However, this approach is too simplistic for explaining the continued existence of ume kbubu. As has been identified, the people who live in ume kbubu may also have their own modern houses, and they consume electricity and use electronic devices, which are signifiers of modern living. The case of the adapted and renewed ume kbubu described below may help to develop an alternative explanation.

Mrs. Yohanna of Oinlasi owns a square-shaped ume $k b u b u$ which she uses as a kitchen and to store corn. The square shape of her ume kbubu is formed from wooden uprights with small gaps between the wood providing ventilation, so that people who are inside can breathe air from the outside. In addition, the kitchen door is taller than a normal adult, so that people who enter into the building do not have to bend. In terms of the preservation of corn stored in this adapted form of ume kbubu, the owner states that the storage period is shorter than for corn stored in original ume kbubu. Her crop can only survive for around two years compared to those stored in other ume kbubu which may last for up to three years. However, she states that this does not matter, because her corn crop is not large and so is consumed quickly by her family. Mrs. Yohanna's kitchen is also illuminated by an incandescent lamp, while ume kbubu are usually lit by kerosene lamps, restricting the lighting in the room.

The Yohanna case illustrates an attempt to perform functional adaptation as a process toward modernization. Kitchen roofing material made of zinc plates instead of grass is another illustration of the form of this renewal process. In addition, the kitchen structure has also begun to meet the basic principles of a healthful house, through the introduction of adequate ventilation and incandescent lighting.

\section{Figure 3-Mrs. Yohana's modified ume kbubu}

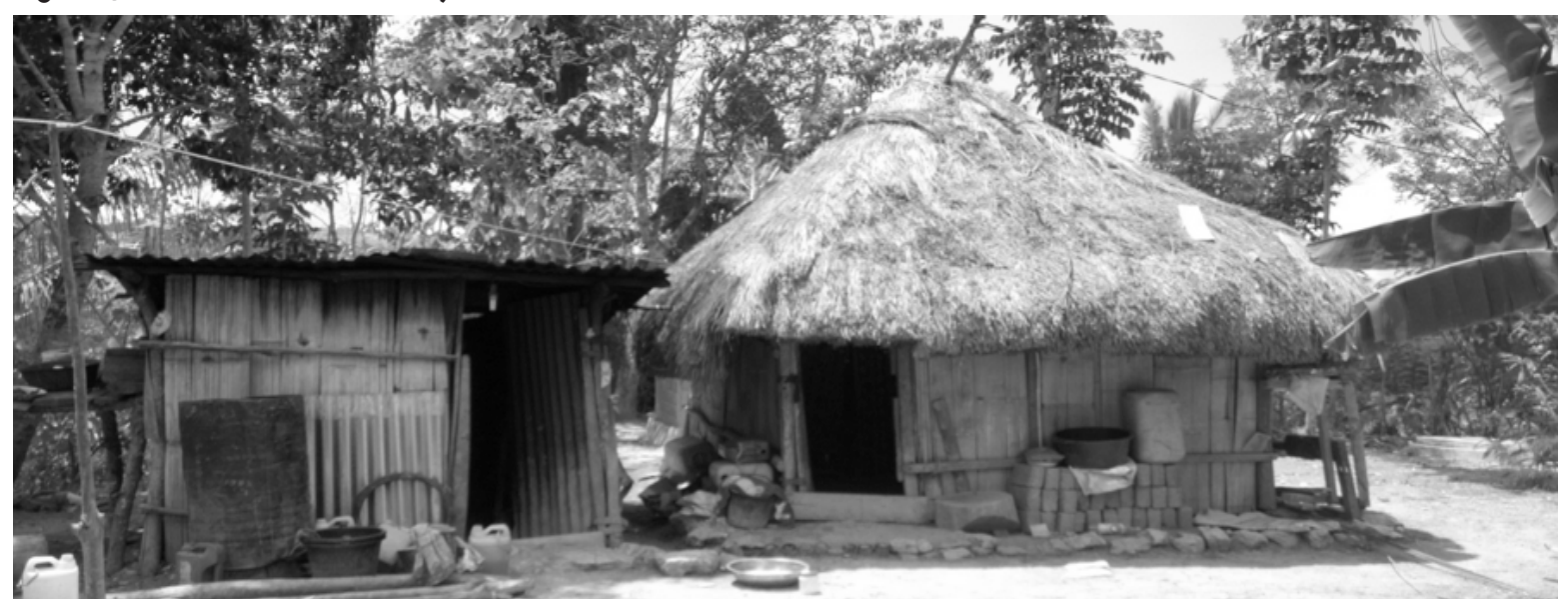


As a concept, modernization is a kind of development that in most cases is initiated by the State. Migdal (2001, p. 199) emphasizes the role of the state in facilitating development and identifies its central role in the process. The State and its representatives perceive themselves as "the modern sector" or the "center"; they are seen as agents and activists in the process of transforming society and are aggressive in their actions. While conventionally it can be perceived as bringing improvements in wellbeing, living standards, and opportunities (Edelman; Haugerud, 2005, p. 1), development may also "refer to historical processes of commodification, industrialization, modernization, or globalization. It can be a legitimizing strategy for states, and its ambiguity lends itself to discourses of citizen entitlement as well as State control". Historically, the State is commonly traced back to the colonial era, therefore theories of development actually also encompass colonial discourses.

Asad (2002, p. 133) presents an interesting view to the role of the state and colonialists. When Europeans led the world as traders, the process of colonization took place, and their troops, missionaries, and government administrators together moved their non-European colonized subjects, with varying degrees of violence, towards a modern stage. These subjects, however, were not passive. Historical reports show how the encounters between Europeans and indigenous people spawned actions such as resistance, adaptation, and cooperation, and illustrate ways in which such peoples tried to reinvent their lives, which had fallen apart after colonization. Asad (2002, p. 134) also illustrates the emergence of new schemes, namely new forms of power, work, and knowledge. It can therefore be interpreted that the imperial dominance of Europeans was not merely a form of temporary repression against non-European societies, but was instrumental in an irrevocable process of transmutation. From the colonization by Europeans, a discourse of hegemony known as 'progress' arose (Asad, 2002) and suggested a dichotomy between developed and underdeveloped, as well as between traditional and modern.

\section{Hybridity and friction}

So how can Mrs. Yohanna's maintaining of her ume kbubu, with its additional and modified features, be explained? In line with Asad's argument regarding the struggle of local practices to survive within development programs, the many dimensions of the changes in ume kbubu need to be investigated. A second case, of Pak Ilyas, an Oinlasi villager who received healthful house aid from the government in 2012 and so has two different types of houses, is examined here:

In 2012, Pak Ilyas received IDR 10,000,000 (US\$ 8,350) from the local government to build a house of predetermined construction. He already had a large, semi-permanent house made of wood and with a grass roof. However, due to its age, the grass roof had started to deteriorate, and the walls were unstable. According to Mr. Ilyas, the house specified by the government had to be built to a size of $5 \times 7$ meters, there were to be windows in front and back of the house, and the door had to be in accordance with the height of a normal adult. During the building, a government official from Timor Tengah Selatan District came to check whether the house was being constructed correctly. However, Pak Ilyas also kept his ume kbubu and maintained its round shape. According to him, ume kbubu must be defended by the Timorese; as long as they still have stocks of family corn, ume kbubu must remain as a place to store them. He is also afraid of being punished by his ancestors if he does not maintain his ume kbubu. Pak Ilyas and his wife still use the ume kbubu for cooking, storing corn, and four of his five children have even been 'smoked' in the ume kbubu. Sleeping and receiving activities take place in the new house.

The same question as was asked with regard to Mrs. Yohanna is applicable to Pak Ilyas: does he belong to 'modern' people by living in a new healthful house? How can his maintaining of ume kbubu and his belief related to the house be explained? The idea or concept of modernization cannot effectively explain the case of Pak Ilyas. Perhaps his case can be seen as an anomaly in modernization? However, many residents in Oinlasi Village have both modern houses and ume kbubu, so can such a case still be considered an anomalous form? 
"I built a family with mama in 1992. Before, I stayed in a big modern house, but after married I built an ume kbubu as a place to cook and store the corn. I have to work at the garden, so I have to have a storage for my harvest. It is a taboo if we married but do not have ume kbubu, where will you place your corn?" Although he has gotten financial aids to build a healthful house, two years after, in 2014, he renovated his ume kbubu. If the new healthful house was financed by government, this traditional house was renovated by the assistance of his relatives both from his and his wife's kin-groups.

As Asad has said, subjects are not passive, even when they are faced with a certain hegemony, and so this means that Pak Ilyas does not simply submit to the hegemony without question. He did consider, and is now practicing, the idea of a healthful house. He said that his wife was often short of breath when she was too long in the kitchen, and therefore at the beginning of their marriage he also built a semi-permanent house. On the other hand, he also believes that ume kbubu is more than just a kitchen. It was his universe, where he and his family performed their daily activities, including sleeping and gathering with family. Thus, he has many memories of being in ume kbubu that he cannot just leave as memories. He feels obliged to keep the traditions of his ancestors alive. In line with his opinion, the community also has the same idea as manifested by the working together among his kin-groups to rebuild his old ume kbubu.

Reuter (2006, p. 11) wrote that "contemporary societies within the South-East Asia Pacific Region still maintain a distinctively Austronesian cultural perspective on the land and territory". The word "distinctive[ly]" refers to a unique "land" relationship of land and territory because there is an intersection between the traditional system and the administrative system of a modern nation State. This unique relationship is created by the influx of external influences brought by globalization. Yohanna and Pak Ilyas' cases also show that, in the practice and knowledge of building houses in Oinlasi, people are now mixing their own perspectives with the standards of modern and healthful houses. This is hybrid knowledge that forms a hybrid type of house (Ara; Rashid, 2016).

A standard is needed to classify an institution or people as traditional or modern. This standard can be seen as similar to the characterization of universality by Tsing (2005). According to her, capitalism, science, and politics depend on global connections that are often thought of as universal. Yet, universality is a product that also arises from the encounters that took place in the colonies. Instead of using it as a primary tool for analysis, Tsing uses the concept of universality (or 'standard') as an entry point to discuss alternative thoughts about the practice of power. As universality is inevitable, she developed the alternative concept of friction to be applied to the study of global connection and its dynamics. Furthermore, she says that friction "is a reminder of the importance of interaction in defining movement, cultural form, and agency" (Tsing, 2005, p. 6). The cases of Pak Ilyas and other Oinlasi villagers who have established a large house but retained their ume kbubu can be well explained using the concept of friction. They are in a struggle both to accept modernity in the form of healthful house and to defend their own practices and ideology by keeping ume kbubu as their houses.

An effort to explain the nexus among civilizations as reflected in a house is provided by Nas (1998). He described the hybridization in many traditional houses in Indonesia as a mixture of the incoming influences from other civilizations traced back to the Hindu, Islam, Chinese, and European periods, and stated that these had colored the style, function, materials used, and other elements, to form the unique configuration of a house. Yet, Nas did not give enough attention to why and how the traditional form of a house is maintained in the contemporary community. The ume kbubu case shows that the influences of civilization have formed neither a modern nor a traditional style of a house; rather they have created the unique features of the strange combination of thatched roof, wooden walls, poor lighting and stifling atmosphere, and the use of incandescent lamps, the sound of transistor radios, and the weaving of products for the market. 
The final explanation of this strange combination or friction (Tsing, 2005) of ume kbubu can be found by referring to what Edelman (2002) and Feldman and Stall (1994) describe as appropriation. They suggest that when an institution or community is characterized as in a dichotomy between modernity and conservatism during the development process, that characterization tends to be inappropriate. Instead, Edelman continues to examine "the capacity of subalterns to appropriate labels (and more complex discourses) and infuse them with new and often positive meanings" (Edelman, 2002, p. 410). It is timely, then, to see ume kbubu in terms of the process of appropriation and giving the community the authority to define their sense of themselves and their place in relation to modern or traditional life.

\section{Conclusion}

The cases of Yohanna and Pak Ilyas illustrate that what they experience is not as simple as attaching a "modern" or "traditional" label to a community. The Oinlasi people are not unaware of government regulations on healthful houses, modernity, and other development programs. They are aware of them. However, there are other important things they cannot ignore and let go in order to live a more modern life, such as building a healthful house to replace ume kbubu. As described above, in addition to having a practical function as a place to store corn, for cooking, and for childbirth, ume $k b u b u$ also has a symbolic function that cannot be replaced by a healthful house. In the midst also of sticking to their label as 'traditional', in this case related to where they live, the people of Oinlasi are also making appropriations that are actualized in their housing. Although they adopt electronic goods, light ume kbubu with lamps, and give birth in a health center, it will be inaccurate to consider them as undertaking functional adaptations to a 'modern' way of life. They are constructing their own definitions, by carefully choosing and selecting new items in their nexus with modernity, and prudently incorporating them in their own new and dynamic cultural configurations.

\section{References}

AMERICAN PUBLIC HEALTH ASSOCIATION.

Committee on the Hygiene of Housing. Basic principles of healthful housing: preliminary report. American Journal for Public Health, Washington, DC, v. 28, p. 351-372, 1938.

ARA, D. R.; RASHID, M. Tracking local dwelling changes in the Chittagong Hills: perspectives on vernacular architecture. Journal of Cultural Geography, Abingdon, v. 33, n. 2, p. 229-246, 2016.

ASAD, T. From the history of colonial anthropology to the anthropology of western hegemony. In: VINCENT, J. (Ed.). The anthropology of politics: a reader in ethnography, theory, and critique. Massachusetts: Blackwell Publishers, 2002. p. 133-142.

CENTRAL BUREAU OF STATISTICS EAST NUSA TENGGARA PROVINCE. Provinsi Nusa Tenggara Timur dalam Angka 2016. Kupang: BPS-Statistics of East Timor Province, 2016.

CENTRAL BUREAU OF STATISTICS OF SOUTH CENTRAL TIMOR DISTRICT. Kecamatan Amanatun Selatan dalam Angka 2017. So'e: BPSStatistics of Timor Tengah Selatan Regency, 2017.

COBBAN, J. L. Public housing in colonial Indonesia 1900-1940. Modern Asian Studies, Cambridge, v. 27, n. 4, p. 871-896, 1993.

DIMA, T. K.; ANTARIKSA, A.; NUGROHO, A. M. Konsep Ruang Ume Kbubu Desa Kaenbaun Kabupaten Timor Tengah Utara. Jurnal RUAS, Jawa Timur, v. 11, n. 1, p. 28-36, 2013.

EDELMAN, M. Peasants against globalization. In: VINCENT, J. (Ed.). The anthropology of politics: a reader in ethnography, theory, and critique. Massachusetts: Blackwell Publishers, 2002. p 408-423.

EDELMAN, M.; HAUGERUD, A. (Eds.) The anthropology of development and globalization: from classical political economy to contemporary neoliberalism. Oxford: Blackwell Publishing, 2005 .

FELDMAN, R. M.; STALL S. The Politics of Space Appropriation: A Case Study of Women's Struggles for Homeplace in Chicago Public Housing. In: ALTMAN, I.; Churchman A. (Eds.). 
Women and the Environment: Human Behavior and Environment. New York: Plenum Press, 1994. p. 167-199.

GABRIEL, T. The Human Factor in Rural Development. London: Belhaven Press, 1991.

HAMMERSLEY, M.; ATKINSON P. Ethnography: Principles in Practice. New York: Routledge 1993

HARRIS, R. Housing policy for the colonial city: the British and Dutch experience compared, 19011949. Urban Geography, Abingdon, v. 30, n. 8, p. $815-837,2009$.

KRIEGER, J.; HIGGINS, D. L. Housing and health: time again for public health action. American Journal for Public Health, Washington, DC, v. 92, n. 5, p. 758-768, 2002.

LEAMAN, D. J. et al. Malaria remedies of the Kenyah of the Apo Kayan, East Kalimantan, Indonesian Borneo: a quantitative assessment of local consensus as an indicator of biological efficacy. Journal of Ethnopharmacology, Limerick, v. 49, n. 1, p. 1-16, 1995.

MARIA, S.; LIMBENG, J.; SUNARTO, A. Kepercayaan komunitas adat suku Dawan pada siklus ritus tani lahan kering di Kampung Maslete, Kecamatan Kefamenanu Kabupaten Timor Tengah Utara, Provinsi Nusa Tenggara Timur. Jakarta: Direktorat Kepercayaan terhadap Tuhan YME, 2006.

MCWILLIAM, A. Mapping with metaphor: cultural topographies in West Timor. In: FOX, J. J.

(Ed.). The poetic power of place: comparative perspectives on Austronesian ideas of locality. Canberra: Australian National University, 2006. p. 101-114.

MIGDAL, J. State in society: studying how states and societies transform and constitute one another. Cambridge: Cambridge University Press, 2001.

NAS, P. J. M. The house in Indonesia: between globalization and localization. Bijdragen tot de Taal-, Land-en Volkenkunde, Leiden, v. 154, n. 2, p. 335-360, 1998.

PRASODJO, R. et al. Advocate program for healthy traditional houses, Ume Kbubu, in a Timor Community: preserving traditional behavior and promoting improved health outcomes. Journal of Health Communication, Philadelphia, v. 20, p. 10-19, 2015. Suplemento 1.

RANTETAMPANG, A. L. et al. Sulfur dioxide (SO2) and nitrogen dioxide (NO2) indoor honai pollution in Wamena, Papua Province, Indonesia. International Journal of Scientific and Research Publications, [s.l.], v. 3, n. 11, p. 337-346, 2013.

REUTER, T. Sharing the Earth, dividing the land: land and territory in the Austronesian world. Canberra: ANU Press, 2006.

SITUMEANG, V. S. N. Ume Kbubu: household granary and food security in Timor Tengah Selatan. 2013. Dissertação (Mestrado em International Studies) - University of Oregon, Eugene, 2013.

TSING, A. L. Friction: an ethnography of global connection. Princeton: Princeton University Press, 2005.

WADU, J. et al. Sejarah Pemerintahan Kabupaten Timor Tengah Selatan: Studi Tentang Pemerintahan Kabupaten Timor Tengah Selatan dari Masa ke Masa. Kupang: Lembaga Penelitian Universitas Nusa Cendana dan Pemerintah Kabupaten Timor Tengah Selatan, 2003.

WATERSON, R. The living house: an anthropology of architecture in South-East Asia. Singapura: Oxford University Press, 1990.

WINDI, Y. K.; WHITTAKER, A. Indigenous round houses versus "healthy houses": health, place and identity among the Dawan of West Timor, Indonesia. Health \& Place, Exford, v. 18, n. 5, p. 1153-1161, 2012.

\section{Authors' contribution}

Purwanto was responsible for directing the research and data analysis. Hapsari collected and analyzed the data. Both authors contributed in the manuscript creation.

Received: 10/20/2017

Resubmitted: 01/09/2018

Approved: 03/26/2018 